\title{
Bat flies on phyllostomid hosts in the Cerrado region: component community, prevalence and intensity of parasitism
}

\author{
Alan Eriksson ${ }^{1 /+}$, Gustavo Graciolli², Erich Fischer ${ }^{2}$ \\ ${ }^{1}$ Programa de Pós-Graduação em Ecologia e Conservação ²Departamento de Biologia, Universidade Federal de Mato Grosso do Sul, \\ 79070-900 Campo Grande, MS, Brasil
}

\begin{abstract}
Streblidae flies are specialised parasites of bat hosts, mainly phyllostomids. There is a high richness of streblids in the savannah-like Cerrado region; however, there is little quantitative data available in parasitological indices. Here, we describe the component community, prevalence and intensity of a streblid infestation on a phyllostomid bat assemblage in Serra da Bodoquena, a Cerrado region in Southwest Brazil. We conducted surveys by capturing and inspecting bat hosts during the seven-month period between October 2004-December 2005. All the ectoparasites found on the bats were collected in the field and then counted and identified in the laboratory. We captured 327 bats belonging to 13 species, of which eight species were parasitized by 17 species of streblids. Carollia perspicillata and Glossophaga soricina were infested with seven streblid species, whereas the other bat species were infested with four or fewer streblid species. Megistopoda proxima and Aspidoptera falcata flies were found on Sturnira lilium, and Trichobius joblingi was the most prevalent fly on C. perspicillata. Megistopoda aranea and Aspidoptera phyllostomatis were highly prevalent and had a high intensity of infestation on Artibeus planirostris. Overall comparisons of the available data suggest that the component communities of streblids vary more between the Cerrado and Atlantic Forest phytogeographical regions than between localities within the same phytogeographical region.
\end{abstract}

Key words: Phyllostomidae - savannah - Serra da Bodoquena - Streblidae

Two families of Calyptratae fly species, Nycteribiidae and Streblidae, are specialised parasites of bats (Dick \& Patterson 2006). Species of Streblidae are cosmopolitan, highly diverse in the New World and mainly associated with bats in the family Phyllostomidae (Dittmar et al. 2006). Seventy out of the 230 species of Streblidae have been recorded in Brazil, which likely underestimates the real number, given that there are several phytophysiognomies in the vast Brazilian territory where bat flies have been poorly studied (Dick \& Graciolli 2006, Graciolli et al. 2008, Dias et al. 2009). Factors intrinsic to bat hosts, such as body size, grooming behaviour and immunological defences, are thought to affect the parasitism of streblids (ter Hofstede \& Fenton 2005, Patterson et al. 2007, 2008). Furthermore, factors extrinsic to the host body, such as the different types of bat roosts and the sharing of roosting places among individual bats and among different bat species, can affect the distribution and abundance of streblids on host populations (Patterson et al. 2007).

Surveys of Streblidae species on bat hosts indicate that the richness of Streblidae is higher in the savannahlike Cerrado region than in the other Brazilian phytogeographical regions (Graciolli \& Coelho 2001, Graciolli \& Aguiar 2002, Graciolli et al. 2006a, 2008, 2010).

Financial support: FBCN, FUNDECT, CNPq

+ Corresponding author: aferiksson@hotmail.com

Received 9 September 2010

Accepted 24 November 2010
However, there are only two studies that describe quantitative parasitological indices for the streblid communities in the Cerrado region (Coimbra et al. 1984, Komeno \& Linhares 1999). Such studies have often been conducted in the Atlantic Forest region (Graciolli et al. 2008) and a few published surveys are available for other Brazilian regions, such as the Caatinga and Amazonia regions (Rios et al. 2008, Dias et al. 2009). In this paper, we describe the component community, the prevalence and the intensity of the infestation of streblid flies on a phyllostomid bat assemblage in Serra da Bodoquena, located in the southwest Cerrado region. We then compared these data to the results from other studies conducted in Cerrado and Atlantic Forest regions.

\section{MATERIALS AND METHODS}

The study was conducted in the southern part of the Serra da Bodoquena National Park, on the Campo Verde farm $\left(21^{\circ} 24^{\prime} 48^{\prime \prime} \mathrm{S}, 56^{\circ} 46^{\prime} 32^{\prime \prime} \mathrm{W}\right)$, which is located in the municipality of Jardim, Mato Grosso do Sul (MS), Brazil. The wet summer and dry winter climate is classified as Aw using the Köppen climate classification system (Köppen 1948). Annual rainfall ranges from 1,000-1,700 $\mathrm{mm}$; the average temperature during the coldest month (July) ranges from $15-20^{\circ} \mathrm{C}$ (Campelo et al. 1997). The predominant vegetation is composed of savannah forests associated with karstic reliefs and rocky soils (Boggiani et al. 1999, Cunha et al. 2009).

Surveys of the streblid species were conducted by capturing bat hosts during October and December 2004 and February, April, June, October and December 2005. In each month surveyed, bats were mist-netted during two consecutive nights at different localities. Each night, 
four mist-nets $(12 \times 2.8 \mathrm{~m})$ were kept open during a sixhour period starting at dusk. Mist-nets were visited at 30 min intervals and the captured bats were then transferred to individual cloth bags prior to being inspected for parasites, which we conducted in the field the same night. To avoid contamination, the cloth bags were only used once during each field trip and were then carefully cleaned between expeditions. All the ectoparasites found on the bat hosts were collected and stored in $1.5-\mathrm{mL}$ plastic microcentrifuge tubes containing $70 \%$ ethanol.

We identified bat hosts to the species level using Vizotto and Taddei (1973) and Anderson (1997). At least three individual bats per species were collected to confirm the identifications and were deposited as vouchers in the zoological collection at the Federal University of Mato Grosso do Sul (ZUFMS). Identification of the bat flies was performed in the laboratory using a stereomicroscope and was based on studies by Wenzel et al. (1966), Wenzel (1976) and Guerrero $(1995,1996)$. Streblid voucher specimens were also deposited in the ZUFMS collection. Taxonomic classifications followed Simmons (2005) for bats and Dick and Graciolli (2006) for ectoparasites. However, we used Artibeus planirostris instead of Artibeus jamaicensis Leach, 1821 (Larsen et al. 2007).

Definitions of component community (the assemblage of parasite species on a given bat species), prevalence (the percentage of bats infested by the same parasite species) and intensity of infestation (the number of parasitic flies per parasitized bat) followed Bush et al. (1997). Confidence intervals were calculated using Quantitative Parasitology 3.0 (Rózsa et al. 2000). Nonprimary infestations (Dick 2007) were not considered for the comparisons with other studies.

\section{RESULTS}

We captured 327 individual bats belonging to 13 Phyllostomidae species. Eight species of bats $(n=132$ individuals) were parasitized by 17 species of streblids $(\mathrm{n}=315$ individuals) (Table). Carollia perspicillata and Glossophaga soricina were infested by seven streblid species, A. planirostris and Sturnira lilium were infested by four streblids, and other bats were infested by two or fewer species. The absence of streblids on non-parasitized bat species was based on only one to four mist-netted individuals, except for Artibeus lituratus $(\mathrm{n}=22)$, which was consistently not parasitized by streblids. Discarding accidental or transitory occurrences (Table), we recorded three streblid species on A. planirostris, the most abundant bat species at the study site. Megistopoda aranea and Aspidoptera phyllostomatis were the most prevalent (34.1\% and $24.7 \%$, respectively) and had the highest intensity of infestation (1.79 and 2.0, respectively) on $A$. planirostris. Two non-transitory streblid species parasitized S. lilium, Megistopoda proxima ( prevalence $=33.8 \%$; mean intensity of infestation $=2.04$ ) and Aspidoptera falcata (prevalence $=21.4 \%$; intensity of infestation $=1.35$ ). Of the three streblid species infesting C. perspicillata, Trichobius joblingi was the most prevalent (40.5\%). Three non-transitory streblid species were recorded on the bat G. soricina, all with prevalences lower than $10 \%$.

\section{DISCUSSION}

Component communities - The component community of bat flies on A. planirostris was richer in Serra da Bodoquena National Park than in other localities in the Cerrado region, even when considering only nontransitory streblid species. In Minas Gerais, Komeno and Linhares (1999) only found M. aranea, and in Goiás, Graciolli and Aguiar (2002) found A. phyllostomatis and $M$. aranea streblids on the bat $A$. planirostris. These streblid species were also recorded on A. planirostris in two additional localities of the Cerrado region in MS (Graciolli et al. 2006a); M. aranea was also found on $A$. planirostris in the Atlantic Forest region (G Graciolli et al. 2008). Therefore, this is the first report where $\mathrm{Me}$ telasmus pseudopterus was found as an additional nontransitory streblid on A. planirostris. However, M. pseudopterus has already been reported on Artibeus obscurus (Bertola et al. 2005), but we recorded no streblids on this bat species in Serra da Bodoquena.

The component community of bat flies on S. lilium in Serra da Bodoquena does not differ from other localities in the Cerrado region (Komeno \& Linhares 1999, Graciolli \& Aguiar 2002, Graciolli et al. 2006a), but in the Atlantic Forest region this bat is parasitized by the endemic fly Trichobius phyllostomae (Bertola et al. 2005, Rui \& Graciolli 2005, Graciolli \& Bianconi 2007), in addition to M. proxima and A. falcata, which are also found in the Cerrado region.

On the bat $C$. perspicillata, the component community of non-transitory streblids in Serra da Bodoquena was richer than in the other localities in the Cerrado region due to the added presence of Speiseria ambigua. Only T. joblingi and Strebla guajiro have previously been reported on C. perspicillata in the Cerrado region (Komeno \& Linhares 1999, Graciolli et al. 2010). These two streblid species and Paraeuctenodes similis have been found on C. perspicillata in the Atlantic Forest region (Bertola et al. 2005, Graciolli et al. 2008).

The non-transitory streblids recorded on G. soricina at our study site, Strebla curvata, Trichobius uniformis and Trichobius dugesii, are the same species found in other localities of the Cerrado region (Graciolli \& Coelho 2001, Graciolli et al. 2010). However, component communities of streblids on $G$. soricina differed between bat populations in the Cerrado and Atlantic Forest regions. T. dugesii is the only species that parasitizes G. sorici$n a$ in both regions, whereas Anastrebla caudiferae and Trichobius lonchophyllae have only been reported in the Atlantic Forest region (Graciolli \& Rui 2001, Azevedo \& Linardi 2002, Bertola et al. 2005).

We discovered that Trichobius angulatus is another non-transitory streblid that parasitizes Platyrrhinus lineatus in Brazil. In other localities in the Cerrado and Atlantic Forest regions, $P$. lineatus appears to be infested only by Paratrichobius longicrus (Komeno \& Linhares 1999, Azevedo \& Linardi 2002, Bertola et al. 2005, Graciolli et al. 2010). In reality, $P$. longicrus is a species complex that is found on the bat genera Artibeus, Uroderma and Platyrrhinus. The "true" P. longicrus would be recorded on only A. lituratus, which is regarded as its 
TABLE

Streblid species collected on phyllostomid bats in the Serra da Bodoquena National Park, Southwestern Brazil

\begin{tabular}{|c|c|c|c|}
\hline $\begin{array}{l}\text { Host (n) } \\
\quad \text { Streblidae (n) }\end{array}$ & $\mathrm{IH}$ & $\begin{array}{c}\mathrm{P} \\
(95 \% \mathrm{CI})\end{array}$ & $\begin{array}{c}\text { MI } \\
(95 \% \mathrm{CI})\end{array}$ \\
\hline \multicolumn{4}{|l|}{ Carollia perspicillata (L., 1758) (42) } \\
\hline Trichobius joblingi Wenzel 1966 (48) & 17 & $40.5(25.6-56.7)$ & $2.8(2.12-3.65)$ \\
\hline Strebla guajiro (Garcia \& Casal, 1965) (5) & 4 & $9.5(2.7-22.6)$ & $1.3(1.00-1.50)$ \\
\hline Speiseria ambigua Kessel, 1925 (2) & 2 & $4.8(0.6-16.2)$ & $1.00^{b}$ \\
\hline Aspidoptera falcata Wenzel $1976(4)^{a}$ & 1 & $2.4^{b}$ & $4.00^{b}$ \\
\hline Aspidoptera phyllostomatis (Perty, 1833) (1) ${ }^{a}$ & 1 & $2.4^{b}$ & $1.00^{b}$ \\
\hline Megistopoda aranea (Coquillet, 1899) (3) ${ }^{a}$ & 1 & $2.4^{b}$ & $3.00^{b}$ \\
\hline Megistopoda proxima (Séguy, 1926) (2) ${ }^{a}$ & 1 & $2.4^{b}$ & $2.00^{b}$ \\
\hline Total (65) & 20 & $47.6(32.0-62.6)$ & $3.3(2.50-4.00)$ \\
\hline \multicolumn{4}{|l|}{ Glossophaga soricina (Pallas, 1766) (42) } \\
\hline Trichobius dugesii Townsend 1891 (7) & 4 & $9.5(2.7-22.6)$ & $1.8(1.00-2.50)$ \\
\hline Strebla curvata Wenzel, 1976 (3) & 2 & $4.8(0.6-16.2)$ & $1.5^{b}$ \\
\hline Trichobius uniformis Curran 1935 (5) & 2 & $4.8(0.6-16.2)$ & $2.5^{b}$ \\
\hline Aspidoptera falcata $(2)^{a}$ & 1 & $2.4^{b}$ & $2.0^{b}$ \\
\hline Megistopoda proxima $(2)^{a}$ & 1 & $2.4^{b}$ & $2.0^{b}$ \\
\hline Speiseria ambigua $(1)^{a}$ & 1 & $2.4^{b}$ & $1.0^{b}$ \\
\hline Trichobius sp. (1) & 1 & $2.4^{b}$ & $1.0^{b}$ \\
\hline Total (21) & 11 & $26.2(13.9-42.0)$ & $1.8(1.27-2.45)$ \\
\hline \multicolumn{4}{|l|}{ Artibeus planirostris Spix, 1823 (85) } \\
\hline Megistopoda aranea (52) & 29 & $34.1(24.2-45.2)$ & $1.8(2.45-2.38)$ \\
\hline Aspidoptera phyllostomatis (42) & 21 & $24.7(16.0-35.3)$ & $2.0(1.48-2.57)$ \\
\hline Metelasmus pseudopterus Coquillet, 1907 (4) & 3 & $3.5(0.7-10.0)$ & $1.3(1.00-1.67)$ \\
\hline Trichobius joblingi $(3)^{a}$ & 2 & $2.4(0.3-8.3)$ & $1.5(1.00-1.50)$ \\
\hline Total (101) & 43 & $50.6(39.5-61.6)$ & $2.4(1.86-2.88)$ \\
\hline \multicolumn{4}{|l|}{ Sturnira lilium (E. Geoffroy, 1810) (80) } \\
\hline Megistopoda proxima (56) & 27 & $33.8(23.6-45.2)$ & $2.0(1.67-2.37)$ \\
\hline Aspidoptera falcata (23) & 17 & $21.3(13.0-31.8)$ & $1.4(1.06-1.71)$ \\
\hline Trichobius joblingi (4) ${ }^{a}$ & 2 & $2.5(0.3-8.6)$ & $2.0^{b}$ \\
\hline Trichobius uniformis $(1)^{a}$ & 1 & $1.3(0.03-6.8)$ & $1.0^{b}$ \\
\hline Total (84) & 39 & $48.8(37.4-60.2)$ & $2.1(1.74-2.59)$ \\
\hline \multicolumn{4}{|l|}{ Platyrrhinus lineatus (E. Geoffroy, 1810) (31) } \\
\hline Trichobius angulatus Wenzel, 1976 (14) & 7 & $22.6(9.6-41.1)$ & $2.0(1.14-3.86)$ \\
\hline Paratrichobius aff. longicrus (Miranda Ribeiro, 1907) (7) & 4 & $12.9(3.6-29.8)$ & $1.8(1.00-2.50)$ \\
\hline Total (21) & 10 & $32.3(16.7-51.3)$ & $2.1(1.10-4.70)$ \\
\hline \multicolumn{4}{|l|}{ Desmodus rotundus (E. Geoffroy, 1810) (10) } \\
\hline Strebla wiedemanni Kolenati, 1856 (18) & 6 & $60.0(26.2-87.9)$ & $3.0(1.67-3.67)$ \\
\hline Aspidoptera phyllostomatis (1) ${ }^{a}$ & 1 & $10.00^{b}$ & $1.00^{b}$ \\
\hline Total (19) & 7 & $70.0(34.8-93.3)$ & $2.7(1.57-3.43)$ \\
\hline \multicolumn{4}{|l|}{ Anoura caudifera (E. Geoffroy, 1818) (5) } \\
\hline Trichobius tiptoni Wenzel, 1976 (1) & 1 & $20.0^{b}$ & $1.0^{b}$ \\
\hline Total (1) & 1 & $20.0^{b}$ & $1.0^{b}$ \\
\hline \multicolumn{4}{|l|}{ Chrotopterus auritus (Peters, 1856) (2) } \\
\hline Strebla chrotopteri Wenzel, 1976 (3) & 1 & $50.0^{b}$ & $3.0^{b}$ \\
\hline Total (3) & 1 & $50.0^{b}$ & $3.0^{b}$ \\
\hline Artibeus lituratus (Olfers, 1818) (22) & 0 & - & - \\
\hline Artibeus obscurus (Schinz, 1821) (4) & 0 & - & - \\
\hline Chiroderma doriae Thomas, 1891 (2) & 0 & - & - \\
\hline Micronycteris megalotis (Gray, 1842) (1) & 0 & - & - \\
\hline Pygoderma bilabiatum (Wagner, 1843) (1) & 0 & - & - \\
\hline
\end{tabular}

$a$ : non-primary associations (Dick 2007); $b$ : insufficient data to calculate confidence intervals (CI); IH: number of infested host individuals; MI: mean intensity of infestation; P: prevalence (\%). 
primary host (Wenzel et al. 1966, Wenzel 1976). However, A. lituratus was not parasitized by P. longicrus or other streblids in Serra da Bodoquena. Thus, the specimens named $P$. longicrus found on P. lineatus are likely a new species whose distribution may be restricted to the Cerrado region.

In the Cerrado region, the component communities of bat flies on Desmodus rotundus is comprised of Strebla wiedemanni, Trichobius furmani and Trichobius parasiticus (Graciolli et al. 2008, 2010), but only $S$. wiedemanni parasitized this bat at our study site. In the Atlantic Forest region, Trichobius dugesioides also parasitizes D. rotundus (Bertola et al. 2005). The occurrence of Trichobius tipton on the bat Anoura caudifer and the occurrence of Strebla chrotopteri on the bat Chrotopterus auritus would be expected based on parasite-host associations published for other sites in the Cerrado and Atlantic Forest regions (Bertola et al. 2005, Graciolli et al. 2008). The absence of bat flies on A. obscurus, Chiroderma doriae, Micronycteris megalotis and Pygoderma bilabiatum may be due to our small sample size (number of captured bats) for these host species. However, even with large collections of bats, Bertola et al. (2005) also found no streblids on P. bilabiatum at a site in the Atlantic Forest region. Furthermore, streblids have not been recorded on C. doriae or M. megalotis in the Cerrado or Atlantic Forest regions.

Prevalence and intensity of infestation - The prevalence of M. proxima on S. lilium (33.8\%) in Serra da Bodoquena was similar to that $(34 \%)$ found at other sites in the Cerrado region (Komeno \& Linhares 1999), but intermediate compared to sites in the Atlantic Forest region (20-60\%) (Bertola et al. 2005, Graciolli et al. 2006b, Graciolli \& Bianconi 2007). Thus, the prevalence of M. proxima on S. lilium appears to be more variable throughout the Atlantic Forest region than in the Cerrado region. However, the prevalence of $A$. falcata on S. lilium was variable (10-32\%) in both the Cerrado and Atlantic Forest regions (Komeno \& Linhares 1999, Graciolli et al. 2006b, Graciolli \& Bianconi 2007).

The prevalence of $T$. joblingi on $C$. perspicillata in Serra da Bodoquena (40.5\%) was lower than at other sites in the Cerrado or Atlantic Forest regions $(>60 \%)(\mathrm{Ko}-$ meno \& Linhares 1999, Bertola et al. 2005, Anderson \& Filho 2006), except for one study in the Atlantic Forest region (10.8\%) (Graciolli et al. 2006b). The prevalence of $P$. longicrus on $P$. lineatus at our study site was similar to that at another site in the Cerrado region (Komeno \& Linhares 1999); the prevalence of streblids on G. soricina is usually low (Graciolli \& Rui 2001, Bertola et al. 2005), such as we found in Serra da Bodoquena $(<10 \%)$.

The intensities of infestation for $M$. proxima $\left(2.0^{1.67-}\right.$ ${ }^{2.37}$ ) and A. falcata $\left(1.4^{1.06-1.71}\right)$ on S. lilium in Serra da Bodoquena were similar to those found in all the other studies performed in the Cerrado or Atlantic Forest regions (Komeno \& Linhares 1999, Rui \& Graciolli 2005, Graciolli et al. 2006b, Graciolli \& Bianconi 2007). These results show a similar per bat pattern of infestation on S. lilium between sites in the Cerrado and Atlantic Forest regions. Otherwise, the intensity of infestation of $T$. joblingi on $C$. perspicillata in Serra da Bodoquena (2.82 $2.12-3.65)$ does not differ from that (2.1) of another Cerrado region (Komeno \& Linhares 1999) but is higher than that (1.4) reported in the Atlantic Forest region (Graciolli et al. 2006b).

Overall comparisons of the available data suggest that the component community of streblids varies more between the Cerrado and Atlantic Forest phytogeographical regions than between sites within the same phytogeographical region. Therefore, environmental conditions likely play a role in local bat fly associations, which lead to variable component communities across a wide distribution of the host species (Wenzel et al. 1966). Prevalence patterns vary extensively between sites, but there is not an apparent pattern associated with phytogeographical domains. Local host abundance and shelter type are thought to affect the prevalence of streblids (Arneberg et al. 1998, Patterson et al. 2007). Therefore, the data available on streblids support the theory that conspecific bats use variable shelters throughout their distributional range and/or that bat species vary widely in their abundance within a phytogeographical region. However, the intensity of infestation of streblids on a host species does not vary as much between sites, even between different phytogeographical regions. Factors intrinsic to the host species, such as body mass, grooming behaviour and immunological defences, could limit the number of bat flies on host individuals (Overal 1980). Additional studies at multiple sites are needed to verify the possible patterns of bat fly associations discussed in this study.

\section{ACKNOWLEDGEMENTS}

To Andréa Araujo, Fernando Paiva, Josué Raizer, Luiz Felipe Carvalho, Luiz Onofre de Souza, Maurício Moura and Silvio Nihei, for suggestions on early versions, to Jason Weckstein, for English revision, to Gabriela Fernandes, for help during field work, and to Carolina Santos, for bat identifications.

\section{REFERENCES}

Anderson R, Filho HO 2006. Dípteros ectoparasitas (Diptera, Streblidae) de filostomídeos (Chiroptera, Mammalia) do Parque Municipal no Cinturão Verde de Cianorte, Paraná, Brasil,e sua incidência ao longo das estações do ano. Chirop Neotrop 12: 238-243.

Anderson S 1997. Mammals of Bolivia, taxonomy and distribution. Bull Am Mus Nat Hist 231: 1-652.

Arneberg P, Skorping A, Grenfell B, Read AF 1998. Host densities as determinants of abundance in parasite communities. Proc Biol Sci 265: 1283-1289.

Azevedo AA, Linardi PM 2002. Streblidae (Diptera) of phyllostomid bats from Minas Gerais, Brazil. Mem Inst Oswaldo Cruz 97: 421-422.

Bertola PB, Aires CC, Favorito SE, Graciolli G, Amaku M, Pintoda-Rocha R 2005. Bat flies (Diptera: Streblidae, Nycteribiidae) parasitic on bats (Mammalia: Chiroptera) at Parque Estadual da Cantareira, São Paulo, Brazil: parasitism rates and host-parasite associations. Mem Inst Oswaldo Cruz 100: 25-32.

Boggiani PC, Coimbra AM, Gesicki ALD, Sial AN, Ferreira VP, Ribeiro FB, Flexor JM 1999. Tufas calcárias da Serra da Bodoquena. In C Schobbenhaus, DA Campos, ET Queiroz, M Winge, M Berbert-Born (eds.), Sítios geológicos e paleontológicos do Brasil, [cited 2010 ago 10], Avaliable from: http://www.unb.br/ig/ sigep/sitio034/sitio034.htm. 
Bush AO, Lafferty KD, Lotz JM, Shostak AW 1997. Parasitology meets ecology on its own terms: Margolis et al. revisited. J Parasitol 83: 575-583.

Campelo Jr JH, Sandanielo A, Caneppele CR, Soriano BMA 1997. Climatologia. In Plano de conservação da bacia do alto Paraguai - PCBAP Meio Físico, Ministério do Meio Ambiente, Brasília, p. 309-349.

Coimbra CEA Jr, Guimarães LR, Mello DA 1984. Ocorrência de Streblidae (Diptera: Pupipara) em morcegos capturados em regiões de Cerrado do Brasil Central. Rev Bras Entomol 28: 547-550.

Cunha NL, Fischer E, Carvalho LFAC, Santos CF 2009. Bats of Buraco das Araras natural reserve, Southwestern Brazil. Biota Neotropica 9: 189-195.

Dias PA, Santos CLC, Rodrigues FS, Rosa LC, Lobato KS, Rebelo JMM 2009. Espécies de moscas ectoparasitas (Diptera, Hipoboscoidea) de morcegos (Mammalia, Chiroptera) no estado do Maranhão. Rev Bras Entomol 53: 128-133.

Dick CW 2007. High host specificity of obligate ectoparasites. Ecol Entomol 32: 446-450.

Dick CW, Graciolli G 2006. Checklist of world Streblidae (Diptera: Hippoboscoidea) [database on the Internet]. National Science Foundation. [cited 2010 ago 10]. Avaliable from: http://fm1.fieldmuseum.org/aa/Files/cdick/Streblidae_Checklist_2oct06.pdf.

Dick CW, Patterson BD 2006. Bat flies - obligate ectoparasites of bats. In S Morand, BR Krasnov, R Poulin, Micromammals and macroparasites: from evolutionary ecology to management, Springer-Verlag, Tokio, p. 179-194.

Dittmar K, Porter ML, Murray S, Whiting MF 2006. Molecular phylogenetic analysis of nycteribiid and streblid bat flies (Diptera: Brachycera, Calyptratae): implications for host associations and phylogeographic origins. Mol Phylogenet Evol 38: 155-170.

Graciolli G, Aguiar LS 2002. Ocorrência de moscas ectoparasitas (Diptera, Streblidae e Nycteribiidae) de morcegos (Mammalia, Chiroptera) no Cerrado de Brasília, Distrito Federal, Brasil. Rev Bras Zool 19 (Suppl. 1): 177-181.

Graciolli G, Azevedo AA, Arzua M, Barros-Battesti DM, Linardi PM 2008. Artrópodos ectoparasitos de morcegos no Brasil. In SM Pacheco, RV Marques, CEL Esbérard, Morcegos do Brasil: biologia, sistemática, ecologia e conservação, Armazém Digital, Porto Alegre, p. 123-138.

Graciolli G, Bianconi GV 2007. Moscas ectoparasitas (Diptera, Streblidae e Nycteribiidae) em morcegos (Mammalia, Chiroptera) em área de floresta com Araucária no estado do Paraná, sul do Brasil. Rev Bras Zool 24: 246-249.

Graciolli G, Cáceres NC, Bornschein MR 2006a. Novos registros de moscas ectoparasitas (Diptera, Streblidae e Nycteribiidae) de morcegos (Mammalia, Chiroptera) em áreas de transição Cerrado-floresta estacional no Mato Grosso do Sul, Brasil. Avaliable from: http://www.biotaneotropica.org.br/v6n2/pt/abstract?shortcommunication+bn03206022006.

Graciolli G, Coelho DC 2001. Streblidae (Diptera, Hippoboscoidea) sobre morcegos filostomídeos (Chiroptera, Phyllostomidae) em cavernas do Distrito Federal, Brasil. Rev Bras Zool 18: 965-970.

Graciolli G, Passos FC, Pedro WA, Lim BK 2006b. Moscas ectoparasitas (Diptera: Streblidae) de morcegos filostomídeos (Mammalia, Chiroptera) na Estação Ecológica dos Caetetus, São Paulo, Brasil. Rev Bras Zool 23: 298-299.
Graciolli G, Rui AM 2001. Streblidae (Diptera, Hippoboscoidea) em morcegos (Chiroptera, Phyllostomidae) no nordeste do Rio Grande do Sul, Brasil. Iheringia Ser Zool 90: 85-90.

Graciolli G, Zortea M, Carvalho LFAC 2010. Bat flies (Diptera, Streblidae and Nycteribiidae) in a Cerrado area of state of Goiás, Brazil. Rev Bras Entomol 54: 511-514.

Guerrero R 1995. Catalogo de los Streblidae (Diptera: Pupipara) parásitos de murciélagos (Mammalia: Chiroptera) del Nuevo Mundo. III. Los grupos: dugesii, dunni y phyllostomae del genero Trichobius Gervais, 1844. Acta Biol Venez 15: 1-27.

Guerrero R 1996. Catalogo de los Streblidae (Diptera: Pupipara) parásitos de murciélagos (Mammalia: Chiroptera) del Nuevo Mundo. VI. Streblinae. Acta Biol Venez 16: 1-26.

Komeno CA, Linhares AX 1999. Batflies parasitic on some phyllostomid bats in Southeastern Brazil: parasitism rates and host-parasite relationships. Mem Inst Oswaldo Cruz 94: 151-156.

Köppen W 1948. Climatologia, Fondo de Cultura Economica, Buenos Aires, 479 pp.

Larsen PA, Hoofer SR, Bozeman MC, Pedersen SC, Genoways HH, Phillips CJ, Pumo DE, Baker RJ 2007. Phylogenetics and phylogeography of the Artibeus jamaicensis complex based on Cytochrome- $b$ DNA sequences. J Mammal 88: 712-727.

Overal WL 1980. Host-relations of the batfly Megistopoda aranea (Diptera: Streblidae) in Panama. Univ Kansas Sci B 52: 1-20.

Patterson BD, Dick CW, Dittmar K 2007. Roosting habits of bats affect their parasitism by bat flies (Diptera: Streblidae). $J$ Trop Ecol 23: 177-189.

Patterson BD, Dick CW, Dittmar K 2008. Parasitism by bat flies (Diptera: Streblidae) on neotropical bats: effects of host body size, distribution and abundance. Parasitol Res 103: 1091-1100.

Rios GFP, Sá-Neto RJ, Graciolli G 2008. Fauna de dípteros parasitas de morcegos em uma área de Caatinga do nordeste do Brasil. Chiroptera Neotropical 14: 340-345.

Rózsa L, Reiczigel J, Majoros G 2000. Quantifying parasites in samples of hosts. J Parasitol 86: 228-232.

Rui AM, Graciolli G 2005. Moscas ectoparasitas (Diptera, Streblidae) de morcegos (Chiroptera, Phyllostomidae) no sul do Brasil: associações hospedeiros-parasitos e taxas de infestação. Rev Bras Zool 22: 438-445.

Simmons NB 2005. Order Chiroptera. In DE Wilson, DM Reeder, Mammal species of the world: a taxonomic and geographic reference, Johns Hopkins University Press, Baltimore, p. 312-529.

ter Hofstede HM, Fenton MB 2005. Relationships between roost preferences, ectoparasite density and grooming behaviour of neotropical bats. $J$ Zool 266: 333-340.

Vizotto LD, Taddei V 1973. Chave para a determinação de quirópteros brasileiros, Francal, São José do Rio Preto, 72 p.

Wenzel RL 1976. The Streblidae bat flies of Venezuela (Diptera: Streblidae). Brigham Young Univ Sci B Biol S 20: 1-177.

Wenzel RL, Tipton VJ, Kiewlicz A 1966. The streblid bat flies of Panama (Diptera: Calyptera: Streblidae), In RL Wenzel, VJ Tipton, Ectoparasites of Panama, Field Museum of Natural History, Chicago, p. 405-675. 